\title{
DESPRE (POST)COMUNISMUL ROMÂNESC. TREI FORMULE NARATIVE ŞI TREI STUDII DE CAZ: PETRU CIMPOEȘU, DAN LUNGU ȘI PATRICK MCGUINNESS
}

\section{ANDREEA ZAVICSA}

\section{Universitatea din București}

Abstract: This paper aims to analyze the (post)communism era in Romania, as it is portrayed in the novels of Petru Cimpoeșu, Dan Lungu and Patrick McGuinness. The study wants to highlight three different perspectives on the communist regime, depending on the vision of each writer: the existential shades of gray, in the case of Cimpoesu's novels, the nostalgia of Dan Lungu's characters, but also the perception of the foreign eye on the totalitarian reality in our country, as for Patrick McGuinness. The paper also emphasizes the reasons why the literary theme of communism still arouses such great interest in contemporary literature and the importance of reading such works through the filter of the present.

Keywords: (post)communism, reality \& fiction, Romania, memories, totalitarism

\section{Introducere}

În 2015 apărea la editura Humanitas volumul colectiv Și eu am trăit in comunism, coordonat de Ioana Pârvulescu. O „culegere” de sentimente, emoții, experiențe trăite, auzite, povestite și repovestite ale cetățenilor României cenușii de sub Ceaușescu. Volumul întrunea fragmente de adevăr, de realitate, așa cum au simțit-o pe pielea lor cei mai bine de 80 de autori reuniți sub același titlu. Miza cărții o constituia rememorarea vieții cotidiene a românilor sub regimul socialist, așa cum se prefigura ea de la abdicarea forțată a regelui, în 1947, și până la execuția soților Ceaușescu în iarna lui 1989. „Fascinația” proprie a subsemnatei pentru regimul apus s-a fondat, fără doar și poate, pe mărturiile celor care au trăit cu adevărat 
în acele timpuri. Capitolul despre comunism din manualele de istorie nu are și nici nu va putea să aibă vreodată același impact asupra generațiilor tinere precum o au cărțile autobiografice sau, ca în cazul dat, antologiile de amintiri. Pentru că perioada comunismului este mai mult decât un subiect de Bacalaureat. Face parte din istoria recentă și, prin „dezghețul” literaturii de după 1989, își recapătă și își slăbește puterile cu fiecare nouă carte ieșită de sub tipar.

Imediat după prăbușirea sistemului defectuos, scriitori de pretutindeni din Europa au exploatat perioada comunismului în operele lor, astfel încât existența populației sub imperiul terorii și al permanentei stări de paranoia este astăzi una dintre cele mai vehiculate sau clișeizate teme literare din ultimele aproape trei decenii de proză românească și europeană. În acest studiu, îmi propun să analizez trei prozatori contemporani, doi - de origine română (Petru Cimpoeșu și Dan Lungu) și un al treilea de origine tunisiană (Patrick McGuinness). Motivația alegerii celor trei autori este simplă: fiecare dintre ei pune în lumină o altă fațetă a (post)comunismului românesc. De la romanele Firesc (1985) și Simion liftnicul (2001) ale lui Cimpoeșu, în care cenușiul cotidian din comunism și starea de nesiguranță, de incertitudine a oamenilor din perioada imediat următoare Revoluției devin metapersonaje, și până la Sînt o babă comunistă! (2007) al lui Dan Lungu, în care Emilia Apostoae este o nostalgică incurabilă după regimul căzut, este evidentă încercarea de recalibrare a comunismului pe axa formulelor narative din proza noastră. Ochiul observator, din afară, îi aparține lui Patrick McGuinness care, prin romanul Ultimele o sută de zile (2011), mizează pe așa-zisa obiectivitate a unui personaj de origine britanică, stabilit în Bucureștiul lui 1989, capabil să înțeleagă și să simtă lalolaltă cu românii cum o lume se destramă, în termenii lui Chinua Achebe.

$\mathrm{Cu}$ alte cuvinte, demersul acestui studiu este unul comparatist, avându-se în vedere romanele menționate, dar nu numai, pentru a se putea delimita eventuale formule narative ale (post)comunismului românesc, așa cum se desprind din punerea față în față a trei ipostaze diferite. Lucarea are perspectivă literară, urmărind atât critica, cât și istoria literară, precum și perspectivă antropologică și de istorie a mentalităților. Studiul va avea la bază analiza pe text, interpretarea tehnicilor narative sugestive pentru fiecare autor, evidențierea particularităților stilului fiecăruia și, mai ales, surprinderea modului în care este reflectată literar societatea românească (post)comunistă. Astfel, eseul va fi structurat în trei părți: permanentul cenușiu cotidian (cu referire la proza lui Petru Cimpoeșu), nostalgia (având 
ca reper romanul lui Dan Lungu) și ochiul străin (pentru romanul lui McGuinness). În acest fel, societatea (post)comunistă va fi contextualizată în funcție de trei repere: două interne și unul extern, constatându-se, la final, cum aceeași temă literară și istorică este tratată în chei opuse pentru a duce însă la capăt aceeași intenție auctorială.

\section{Permanentul cenuşiu cotidian. Alegoriile lui Petru Cimpoeșu}

Este firesc a începe călătoria în trecutul nu foarte îndepărtat al românilor prin lectura romanului din 1985 al lui Petru Cimpoeșu, scris chiar la finele epocii ceaușiste, sub austeritatea regimului încă în putere, dar care, datorită artificiilor narative deosebit de subtile, reușește să treacă de cenzură și să exploateze întocmai toposul cenușiu al socialismului în România. Romanul Firesc este receptat pozitiv de critica literară pentru fina analiză psihologică a personajelor, care îl anunță pe viitorul autor al lui Simion liftnicul: ,încontinuu hrănit- de aici forța lui-cu o sumedenie de observații din acelea ce dau substanță prozei adevărate și arată că autorul stie foarte multe despre lumea- din jur și cosmică, exterioară și interioarăin care trăiește." Miza cărții o reprezintă încercarea de a crea caractere, individualități, care își duc existența într-un regim politic fără caracter, insensibil și nedemn. Strategia narativă a lui Petru Cimpoeșu e sugestivă în acest sens: structura romanului este bimembră, astfel încât Prologul îl constituie așa-numitul jurnal intim al Iuniei Poenaru, ingineră stagiară la secția Ața-Brateș a întreprinderii Geologice de Explorări, în timp ce Prologul trece deodată la narațiune heterodiegetică, cuprinzându-i, pe rând, pe fiecare dintre colegii de serviciu ai Iuniei, cu gândurile, temerile și experiențele lor. De fapt, accentul cade pe rutina obositoare și anihilatoare în care se adâncesc personajele, până într-atât încât se uită pe sine și nu pot învăța să se dezobișnuiască de monotonie, melancolie, vid.

Suntem în plin comunism; toposul profesional al personajelor trădează acest lucru, iar senzația de claustrare resimțită de cititor la rândul său survine din apetența scriitorului pentru decorul la scară redusă, amintind de camerele dostoievskiene ale mahalalelor. Iunia, stagiară la întreprinderea situată ,în văgăuna asta, la capătul lumii” se întreabă: $C e$ poți face toată ziua când nu ai ce face? Imi tot aranjam camera. Stătuse în ea un sondor-sef care avea probabil fobie de molii, turnase peste tot naftalină. Cu asta mă obişnuisem, dar cu înghesuiala lucrurilor încă nu, le tot potriveam în fel și chip, încercând să câștig cât de puțin spațiu, boală pe care am moștenit-o

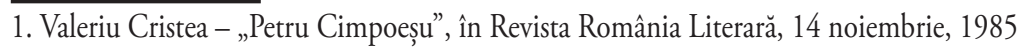


probabil de la mama... ${ }^{2}$ Semnatara jurnalului intim din prolog face nenumărate incursiuni în trecutul propriu, încercând parcă să-și acorde terapia necesară cicatrizării rănilor sufletești. Ni se semnalează, astfel, copilăria și adolescența Iuniei la internat, scurtele întrevederi cu tatăl ei, la anosta cofetărie din oraș, reproșurile mamei, Gigi Poenaru, care își dorea pentru fata ei aceeași faimă de care se bucură ea, cântăreața de muzică ușoară, experiențele eșuate ale Iuniei pe plan sentimental (fire inhibată și excesiv de precaută, tănăra a respins și continuă să respingă orice apropiere masculină), până când suntem readuși în planul prezentului, la noul ei loc de muncă, unul întru totul masculinizant și degradant pentru orice ființă feminină.

De altfel, după cum observa și Radu G. Țeposu, Jurnalul Iuniei dă cel mai bine măsura disponibilitătilor artistice ale prozatorului. Aflăm aici o știință impecabilă de a surpinde banalitatea de care se inconjoară lumea si care devine noua sa mitologie, dar și capacitatea de a evoca fragmente de trecut în toată prospețimea și naturalețea lor... ${ }^{3}$. De ce anume REsimte claustrarea? Pentru că aglomerația strivitoare de obiecte din cutia ei de chibrituri este doar exteriorul compartimentului sufletesc, un suflet doldora de emoții, de trăiri, de sentimente exacerbate tocmai din neputința de a le împărtăși cuiva, din teama de singurătate copleșitoare care a pus stăpânire iremediabil pe tot psihicul ei. Bineînțeles că după ce mi-am aranjat totul, câteva zile, până m-am obișnuit, nu mai puteam sta inăuntru decât culcată și cu ochii închiş̧i, dacă îi deschideam mi se părea că nu am aer. Abia așa înțelegeam rostul multelor bănci din curte și de la birou... ${ }^{4} \mathrm{Ea}$ a fost și este pe tot parcursul firului epic o ființă inhibată, interiorizată și confuză, inadaptată într-un mediu anihilator care îi oferă pentru o secundă o portiță de evadare, în persoana lui Adam, pentru ca imediat după să i-o închidă în față cu putere.

In jurul Iuniei gravitează toată breasla inginerilor petroliști de la secția Ața-Brateș, personaje atât de tipice în ansamblul lor și totuși atât de individualizate prin propriile procese de conștiință. În prima ei zi de lucru, Iunia răspunde ",privirilor surprinse si lacome" ale colegilor cu sfiiciunea feciorelnică a celei care nu și-a însușit încă protocolul și nu știe cui și în ce mod să-i zâmbească, să i se adreseze. Venirea ei constituie un eveniment

2. Petru Cimpoeșu, Firesc, ed. a doua, Editura Polirom, Iași, 2010, p. 35

3. Radu G, Țeposu, „Istoria tragică şi grotescă a întunecatului deceniu literar nouă, Ed. Humanitas, 1993

4. Petru Cimpoeșu, op. cit., pag. 37 
în viețile munictorilor, un prilej de deconectare de la îndatoririle zilnice pentru a savura spectacolul uman ce se desfăşoară sub ochii lor. Sonia însăși îi va mărturisi Iuniei că e ceva în ființa ei care suscită interes și mirare deopotrivă: $\mathrm{Cu}$ toții suntem cele mai grozave și nemaipomenite excepții! De fapt, tocmai de aceea ne-am adunat aici, ca să ne contemplăm reciproc exceptia care ne-a adus (...) Vezi, tocmai asta e povestea; altceva-ul tău. ${ }^{5}$ Raportul de forțe este inegal, tânăra ingineră încearcă să asimileze o mulțime de figuri noi care îi inspiră teamă, nesiguranță, scârbă pe alocuri: Care și cum vorbea? Necunoscându-i, n-avea nici o importanță, oricum $\hat{\imath} i$ confundam. Cum să înveți dintr-odată atâtea nume și cum să le asociezi atâtor fizionomii, de vreme ce ai încă sentimentul că ești liberă față de ele, nu te determină în nici un fel? Formau un tot și totul acesta era nou, făcut anume pentru mine, pentru ziua sosirii mele, prima mea zi de serviciu (....). ${ }^{6}$ Prin ochii Iuniei, ne sunt prezentați colegii ei de secție, ingineri petroliști construiți diferit, aproape antitetic unul față de celălalt, dar reduși la numitorul comun al veșnicei monotonii opresive, fără altă cale de scăpare decât o eventuală sinucidere. Percepțiile Iuniei despre ei sunt punctulcheie al întregii narațiuni, întrucât, dincolo de schițarea rutinei zilnice a inginerului comunist (făcută atât subiectiv, cât și, mai ales, obiectiv de către naratorul ubicuu), analiza psihologică și contopirea eului masculin cu unul feminin marchează adevăratul merit al lui Petru Cimpoeșu. Se desprind din acest tablou Neagoe- o figură care îți făcea această impresie. Că l-ai mai văzut și nu știi de unde să-l iei-, Vendel, geologul -cel pletos, cu față mare, congestionată, mâncată de vărsat, arterele gâtului umflate, gata să crape in orice clipă, Sonia- femeia tânără, şatenă, cu mişcări prudente, care mă cercetă atentă, Adam, inginerul de foraj- tipul înalt, blond și indiferent, care mă privi micşorându-și ochii într-o probabilă tentativă de a-mi inspira complicitate, Robotu, insul scurt si corpolent, fălcos, nebărberit, cu nasul roșu și bombat și niște buze groase, slinoase, pe care și le lingea întruna, care îmi pupă zgomotos mâna, Budu, soțul Soniei- doar un bărbat trecut de treizeci, bine construit, cu o frunte de om nervos, nu știi dacă are inceput de chelie sau așa a fost mereu ${ }^{7}$, formidabilul Buzdea, care a furat mireasa altuia, și multe alte personaje cu care Iunia va intra în contact și le va atribui un statut în relație cu ceilalalți: Tamara, logodnica lui Adam care se visează pe scenă, Gigi Poenaru, mama Iuniei și renumită cântăreață

\footnotetext{
5. Ibidem, pag. 122

6. Ibidem, pag. 15

7. Ibidem, pag. 14
} 
de muzică ușoară, Voaiteș, ajuns la o vârstă respectabilă la care încă mai încearcă să priceapă matematica șamd.

Dintre toți, tânărul intelectual Adam Nica este singurul care inițiază o apropiere de altă natură, dar ale cărui intenții rămân neînțelese tocmai pentru că el și Iunia sunt făcuți din același aluat, incapabili amândoi să decodeze semnalele primite de la celălalt și refuzându-și astfel șansa la fericire. El însuși este instabil social și moral: este logodit cu Tamara, o femeie de ale cărei capacități intelectuale reduse cititorul va fi convins, are o aventură cu Sonia, soția lui Budu (relație extraconjugală de care amândoi sunt plictisiți și pe care aproape că nici nu mai încearcă să o ascundă de soțul cu gânduri sinucigașe), dar în același timp se îndrăgostește de inocenta Iunia, captivă în propriile gânduri. Voaiteș își asumă rolul de Eros, încercând să îi apropie pe cei doi pentru a se hrăni cu fericirea lor: Trebuiau găsite deci acele cuvinte speciale care să $̂$ ll facă pe Adam să ințeleagă singur că îi e dragă Iunia, că o iubește, că e o bucurie să-i vezi chipul, să-i vorbești și să-ți vorbească, să respiri in preajma ei, să-i atingi mâna, să o auzi râzând copilărește.. ${ }^{8}$ Cei doi vor prefigura cuplul adamic pentru o scurtă perioadă, căci încercările lui Voaiteș sunt zădărnicite de sinuciderea Iuniei, o moarte de altfel lipsită de orice zbucium, învăluită însă într-o aură de mister. Budu o descoperă în camera ei, l-a surprins: ordinea desăvârșită a camerei, mirosul acela, care o contrazicea, pătura trasă până la gât, acoperindu-i nu numai trupul, ci și mâinile, fața ei umflată, ochii vineți. $N$-a văzut cele două cutii de medicamente (goale) și nici paharul de pe noptieră, dar privind-o a înțeles pe loc că e moartă. ${ }^{9}$ Moartea Iuniei, cauzată cel mai probabil de înghițirea a două cutii de anticoncepționale, este singura doză de nefiresc din economia textului. Sufletul nestatornic al Iuniei, închistat între prologul și epilogul vieții sale, se liniștește subit, prin administrarea pastilelor celor mai nepotrivite cu persoana ei. Este, poate, unica surpriză pe care ne-o rezervăltextul lui Cimpoeșu.

Chintesența romanului o ilustrează cel mai bine însuși firescul regimului pe care personajele îl acceptă făă să i se împotrivească. Tot arsenalul de elemente constitutive ale comunismului sunt integrate armonios în economia textului: de la telefoanele ascultate și veșnicele intervenții ale telefonistei: „Alo, vorbiți?”, până la cozile la alimente: „De când nu mai câștiga mult, devenise zgârcită, nu mai mânca în oraș, nu se mai aproviziona la casele de comenzi, se popularizase, stătea la cozi ca tot

\footnotetext{
8. Ibidem, pag. 209

9. Ibidem, pag. 285
} 
cetățeanul, se tocmea cu țăănci la tarabe (...)"10. Dar ceea ce dă substanța romanului și tenta alegorică este pasajul următor, în care Iunia încearcă să accepte o eventuală siluire din partea Robotului, dar care poate fi lesne interpretat ca o demascare subtilă a regimului comunist din România:

Încercând de atâtea și atâtea ori să-ți învingi repulsia, nu sfârșești prin a ți-o anihila? E un fel de a te adapta la teroare: să o analizezi în toate amănuntele ei și să găsești că amănuntele acelea sunt, în fond, rezonabile, juste, motivate, deci tiranul are dreptate, nu fiindcă ar avea-o efectiv, că ai fi convins de asta, ci fiindcă nu ai de ales decât să previi răul prin bine, să încerci să-l îmbunezi, asimilezi. Este aici, știu, teama de violență, efectul insecurității garantate, promise de o educație teroristă și ea. T,i se spune stăruitor, cu începere de la doi, trei ani, că trebuie să faci numai ce nu-ți place, acesta fiind binele, și că nu ai voie să faci nimic din ceea ce ți-ar putea procura plăcere, fiindcă e rău. Ești terorizat cu untura de pește și trebuie să spui că îți place fiindcă e bună. Altfel n-ai putea-o mânca, și ți se impune s-o mănânci, trebuie! Idealul moral constă într-un fel de autoflagelare în folosul celorlalți. (...) Cine afirmă că untura de pește e împuțită și grețoasă e un copil rău, prost educat și va fi un rău cetățean. Cine afirmă că a făcut cutare faptă nemaipomenită nu pentru societate, ci vizând folosul personal, este blamat ca un nemernic, deși fapta ca atare rămâne... ${ }^{11}$

$\mathrm{Cu}$ alte cuvinte, romanul lui Cimpoeșu poate fi citit și în cheia unei alegorii, astfel încât narațiunea care o are în centru pe Iunia Poenaru cu destinul ei frânt înainte de vreme, cu monotonia și rutina anihilatoare în care se pierd inginerii petroliști, cu incapacitatea lor de a lua decizii majore cu privire la viața lor reprezintă doar un pretext, doar un paravan pentru adevăratele intenții auctoriale ale autorului.

Rămânând în sfera alegoriilor pentru regimul căzut, Petru Cimpoeșu surprinde a doua oară, în 2001, prin apariția romanului Simion liftnicul. Roman cu îngeri și moldoveni. De data aceasta, doar ne amintim de comunism, pentru că acțiunea se petrece la aproape zece ani de la căderea regimului, în 1997, pe fondul instabilității politice, economice și sociale a României capitaliste. Este romanul în care umorul autorului merge mână

10. Ibidem., p. 53

11. Ibidem, p. 57 
în mână cu finețea lui psihologică, Petru Cimpoeșu făcând și din cele mai mici schimburi de replici ori gesturi ale moldovenilor săi tot atâtea fire și noduri caracterizante, persistente în memoria cititorului. ${ }^{12}$ În România postdecembristă a anului 1997, într-un bloc de pe strada Oilor din Bacău, un locatar se blochează în lift la etajul opt, după modelul schivnicilor ortodocși de odinioară. Pornind de la această intrigă, romanul este o frescă la scară mică (!) a României debusolate, care încearcă să își recapete forțele și să încerce un alt drum, dar comite aceleași greșeli din trecut. Focalizarea externă și perspectiva de la particular la general, de la bloc la imaginea întregii țări, la care se adaugă umorul grotesc și onomastica incredibil aleasă a personajelor sunt ingredientele care conferă banalitătiii acel plus de inedit necesar. Pentru că, în definitiv, Petru Cimpoeșu mânuiește în mod exemplar arta de a transforma banalul în spectaculos, de a expune peisajul mioritic în lumină naturală și de a-l lăsa să trăiască. Într-o recenzie la romanul din 2001, Vasile Dan recunoștea că autorul umblă la idei, personaje, conflicte, și nu, așa cum se întîmplă aproape la toţi congenerii lui de astăzi, cu obstinențăa, la exprimarea lor. El plonjează direct în inima unei realităţi social-politice imediate, postdecembriste, cu toată tulburarea și incertitudinile ei. ${ }^{13}$

Vecinul Toma de la patru, avid ascultător al emisiunilor BBC care încep a fi traduse în română dupa Revoluție, Pelaghia, o doamnă de 37 de ani căsătorită, dar care are o aventură secretă cu un alt domn din bloc, „al cărui-nume-îl-trecem-sub-tăcere”, Elefterie Popescu, personaj care a migrat tocmai din paginile caragialene în realitatea ficțională a autorului contemporan, Nicostrat zis Zăvorâtul, profesor de Kama Sutra, Vasile, tatăl Pelaghiei, dornic de a înființa un partid împreună cu Ion-șefulde-scară, vecinul Anghel, funcționarul model chinuit de mâncărimile blestemate ale râiei, Eftimie, profesorul de științe, prins într-un scandal sexual cu eleva Ciobanu Lenuța, Ilie, vecinul de la șapte care își demontează și repară motocicleta pe tot parcursul romanului, poetul Gheorghe, care vorbește în rime și suferă de insomnii acum când nu mai are pentru ce cozi să se trezească devreme, Temistocle, elevul de clasa a VI-a care dă răspunsuri la școală de o inteligență ieșită din comun, impresionând-o pe domnișoara Zenovia, profesoara lui de română și discipolă a lui Nicostrat și, nu în cele din urmă, Simion liftnicul, cizmarul de la parterul bloclui, sunt personaje atât de tipice, atât de pitorești, de obișnuite, dar, totodată,

12. Daniel Cristea-Enache, „La bloc”, în „Ziarul de Duminica”, 6 iunie 2008

13. Vasile Dan, „Un prozator empatic” în „Vatra”, nr. 1-2/2018 
foarte bine particularizate. Locuiesc laolaltă, împart aceeași scară de bloc, același lift, fără a se întâlni dincolo de nelipsitele ședințe de scară. Simion se blochează în liftul pe care și-l transformă în chilie, pentru a se bucura de ședințele sale de spiritim în liniștea ce îi era veșnic tulburată în garsoniera sa de la parter. Fără a putea folosi ascensorul, locatarii sunt nevoiți să urce și să coboare pe scări, întâlnindu-se inevitabil între etaje. Ceea ce Simion ar fi vrut să fie o izolare completă s-a transformat în cea mai mare reuniune din istoria blocului, pentru că, treptat, fiecare personaj află cauza inactivității liftului și i se confesează lui Simion ca unui adevărat preot. Din spatele ușilor liftului, Simion ascultă și rareori răspunde. Până spre finalul romanului, când le va ține adevărate discursuri pilduitoare, liftnicul preferă să își petreacă timpul rugându-se dimineața, la prânz și seara. Dincolo de chilia improvizată, locatarii sunt protagoniștii unei comedii care e viața însăși.

Există, de altfel, și un comic al onomasticii. Toma Necredinciosul este, din contră, foarte credul. Tot ce aude la televizor consideră că vine dintr-o sursă sigură, tocmai de la $\mathrm{BBC}$, la fel cum se încrede și în escrocii care îi oferă ,cadouri” în schimbul unei taxe de transport. Ion-șeful-de-scară este purtătorul celui mai comun nume, semn al nediferențierii sale prin mai nimic față de restul locatarilor. Este un tipicar a cărui mare plăcere este să întocmească anunțuri pentru avizierul blocului și să-și convoace vecinii la ședințe pe care le prezidează cu o mândrie a superiorității asumate. Temistocle, puștiul cu nume atenian, este un intelectual în devenire, un copil sensibil, îndrăgostit de profesoara sa de română. Este la vârsta la care nu poate înțelege că trebuie să încheie un pact ficțional ${ }^{14} \mathrm{cu}$ Mihail Drumeș, astfel încât să nu sufere pentru moartea celor doi îndrăgostiți din Invitația la vals. Inocența lui Temistocle se maturizează prematur odată cu primele gânduri sinucigașe care îi trec prin minte și odată ce înțelege ce se petrece dincolo de peretele despărțitor, în apartamentul lui Nicostrat Zăvorâtul. În mod paradoxal poreclit Zăvorâtul, căci ușa sa nu este niciodată încuiată. Elefterie Popescu este, bineînțeles, Lefter Popescu din Două loturi, avid jucător de Bingo, la rândul său convins că este pe punctul de a încasa marele premiu. Dezamăgirea îl lovește și pe el, dar, spre deosebire de predecesorul său, Elefterie nu se resemnează, ci răbufnește în mod violent, devastând împreună cu soția sa întregul sediu al casei de pariuri. Pelaghia, purtătoare a unui nume sfânt, nu este deloc

14. Pactul ficțional a fost teoretizat de Umberto Eco într-unul dintre eseurile cuprinse în volumul ,Șase plimbări posibile prin pădurea narativă”(1997). 
o neprihănită. Se iubește pe ascuns cu un colocatar, a cărui identitate este ascunsă pe tot parcursul textului. Personajele lui Cimpoeșu fac deliciul cititorului. Surprinse în obișnuitul vieții lor, ele stârnesc repulsia, amuzamentul, indignarea, compătimirea, pe scurt-o gamă largă de sentimente uneori contradictorii. Cu siguranță, la finalul cărții, cititorul va încerca să descrie starea sufletească predominantă și nu va reuși să aleagă niciuna din amalgamul de emoții resimțite. Romanul lui Cimpoeșu este dovada faptului că proza nu trebuie să conțină elemente de fantastic sau de supranatural pentru a ieși din normalul cotidian. În acest sens, Claudiu Turcuș observa că:

Avem de-a face cu un mulaj realist care nu omite nici una din metehnele vieţii la bloc. Mai mult, figurinele închipuite de Cimpoeșu au un aer de naturaleţe, încât parcă vecinii din lumea reală nu sunt decât niște crochiuri mecanice ale lor. În ciuda faptului că se intersectează doar tangenţial, toate aceste micronaraţiuni sfârșesc prin a configura o atmosferă macrosocială atât de specifică după 1989, în care domnește confuzia, dar mai ales setea de miraculos. ${ }^{15}$

Viaţa înșăși, în simplitatea ei obositoare, este motorul întregului roman, subintitulat în cheie ludică Roman cu îngeri și moldoveni. În același mod ludic în care se și încheie, după ce a ascultat păcatele tuturor vecinilor săi, oferindu-le la schimb pilde și vorbe de duh, Simion a deblocat liftul si l-a părăsit de bunăvoie probabil în cursul nopții de 13 spre 14 octombrie 1997. ${ }^{16}$, alături de el plecând și elevul Temistocle dintr-a șasea, de a cărui mână a fost scrisă Parabola blocului de locuințe, dictată din spatele ușilor liftului de mai vârstnicul său partener de drum. Înțelepciunea și inocența pornesc pe un drum neștiut, lăsând în urmă blocul ,,ales”, adică săraca țară bogată, patria noastră, România, așa cum ne-a lăsat-o Ceușescu și cum am făcut-o noi după aceea! ${ }^{17}$

În Simion liftnicul toate cărțile sunt date pe față. Cimpoeșu nu mai are motive să își refuze considerațiile cu privire la regimul apus, drept care acestea sunt tratate fie în cheie acidă, deosebit de ironică sau, din contră, dintr-o izvorâre a înțelepciunii dobândite odată cu trecerea

15. Claudiu Turcuș, „Simion liftnicul, după 15 ani”, în „Vatra”, nr. 1-2/2018

16. Petru Cimpoeșu, Simion liftnicul. Roman cu ingeri și moldoveni, Ed. a 2-a, rev., Ed. Polirom, Iași, 2007, p. 284

17. Petru Cimpoeșu, op. cit., p. 302 
timpului. Constatarea la care ajunge şi Nicolae Manolescu este că: „Simion liftnicul este un roman realist si comic, dovedind o excepțională capacitate de observație socială și psihologică, printre foarte puținele scrise după 1989 care depășesc nivelul gazetăresc ori al pamfletului politic în descrierea lumii noastre noi." 18

Mizând pe umorul alegoric, putem interpreta la nesfârșit observațiile personajelor și narațiunea în sine. Când Simion se adresează vecinilor săi, de dincolo de ușile liftului: „(...) mai mergeți și pe scări. Abia vă întâlniți mai des, mai schimbați o vorbă. N-ai observat că, din cauza cutiei ăsteia, v-ați izolat unii de alții?”" ", „cutia” la care se referă este mai mult decât ascensorul blocului, la scară mai mare, poate fi interpretată ca România comunistă însăși, izolată în blocul sovietic. Esențial în romanul de față este pasajul care anunță, de fapt, rătăcirea unei țări care s-a grăbit către schimbare, dar pe care nu o poate accepta și, implicit, nu i se poate adapta: Să ne oprim puțin și să ne întrebăm: ce vor, de fapt, toți oamenii ăștia, ce caută? Răspunsul nu poate fi decât: caută o confirmare de sine, un sens. Sensul vieții? Nici măcar atât - mai degrabă un sens al propriilor iluzii, cel mult sensul prezentului, al zilei de azi, rareori și al celei de mâine.$^{20} \mathrm{Cu}$ alte cuvinte, cetățenii României, nu doar locatarii blocului din Bacău, sunt surprinși în încercarea de a-și contura individualitățile. Pentru prima dată, sunt puși în situația de a trăi pentru ei înșiși, încep să fie tratați ca atare și nu la comun, ca o masă, dar ei rămân ancorați în trecutul nu foarte îndepărtat și de obişnuința traiului anterior. De aici izvorăște conflictul interior al personajului colectiv, redus de Cimpoeșu la nivelul unui simplu bloc, dar care devine protagonistul schimbării la faţă a României înseși. O Românie al cărei președinte nu poate fi decât Iliescu, așa cum va prezice Simion, nici măcar Isus nefiind în stare să obțină îndeajuns de multe voturi din partea alegătorilor.

\section{Nostalgia. O altă faţă a comunismului în romanul lui Dan Lungu}

Dan Lungu este unul dintre cei mai apreciați și traduși scriitori ai generației de astăzi. Afirmația nu este întâmplătoare, dacă ne raportăm la volumele de proze scurte și la romanele sale traduse în peste zece limbi,

\footnotetext{
18. Nicolae Manolescu, Istoria critică a literaturii române, Ed. Paralela 45, Pitești, 2008, p. 1368

19. Petru Cimpoeșu, Simion liftnicul. Roman cu îngeri și moldoveni, ed. Polirom, Iași, 2011, p. 75
}

20. Petru Cimpoeșu, op. cit., p. 90 
în care autorul evidenţiază, fără pudoare, realitățile vremurilor în care am trăit și pe care le trăim astăzi. Un astfel de roman este şi Sînt o babă comunistă!, apărut în 2007, destul de recent chiar ecranizat în regia lui Stere Gulea.

După cum deja poate reiese și din titlu, menit să atragă cititorul, romanul lui Dan Lungu propune o altă abordare a regimului ceaușist, de data aceasta una mai mult decât favorabilă. La aproape zece ani de la căderea dictaturii ceaușiste, Emilia Apostoae, protagonista cărții, trăiește un conflict care o macină pe interior: Alice, fiica ei stabilită în Canada, o sună și o sfătuiește să nu voteze la alegerile electorale cu „foștii comuniști”, dar, judecând din proprie experiență, pensionara nu poate să se încreadă în partidele noi, căci anii ei de tinerețe au fost petrecuți sub comunism, și, oricât de păcătos ar fi fost regimul cu alții, ei i-a mers bine. Criza identitară este amplificată și de argumentul pe care Emilia îl consideră suprem: „Pe mine comunismul m-a făcut orășeancă!” ${ }^{21}$ Starea de introspecţie a cărţii se apropie de romanul Gabrielei Adameșteanu Dimineaţa pierdută, dar pe dos: în romanul Gabrielei Adameșteanu, eroina pendula între interbelicul distrus de comuniști și realitatea comunistă opresivă, iar aici, Emilia pendulează între comunismul dispărut și prezentul agresiv, capitalist, greu de acceptat. Pas cu pas se deapănă o poveste despre nostalgie, despre relaţia cu memoria, despre schimbarea lentă de perspectivă.

În acest fel, pe tot parcursul romanului, Emilia Apostoae se declară o nostalgică față de regimul căzut, amintindu-și cu drag de adolescența și tinerețea petrecute la oraș, muncind într-un atelier care fabrica produse din tablă pentru export și având asigurată o locuință și bani mai mulți decât restul populației. Ceea ce nu ia în considerare Emilia este faptul ca ea și colegii ei de muncă, cu toții membri de partid, figurau printre puținele excepții favorizate ale regimului. Tocmai din acest motiv romanul lui Dan Lungu este de remarcat; experiențele plăcute ale Emiliei sunt puse în contrast cu ceea ce trăia restul țării, astfel încât argumentele pensionarei sunt contrabalansate de cele ale fiicei din Canada și ale croitoresei Rozalia, realizându-se în câteva pagini o dezbatere echilibrată între două atitudini radical diferite.

Atitudinea reticentă a Emiliei față de noile vremuri pe care le trăiește și cu care nu se poate acomoda este de înțeles dacă ne raportăm nu doar la realitatea ficțională, ci și la cea contingentă. Într-un remarcabil studiu intitulat „Postsocialism and the Politics of Emotions”, apărut în

21. Dan Lungu, Sinnt o babă comunistăl, ed. Polirom, Iaşi, 2011, p. 51 
Postsocialism: politics and emotions in Central and Eastern Europe, autoarea Maruška Svašek explică de unde și de ce apare sentimentul de nostalgie. Ea observă că, în multe cazuri, la mai bine de un deceniu de la căderea regimului comunist, sentimentul inițial de speranță pentru un viitor mai bun a fost imediat înlocuit de deziluzie și scepticism. Șomajul în creștere, diferențele noi apărute între clase, sărăcia, scandalurile de corupție, dezacordurile cu privire la reîmproprietărirea populației cu imobilele confiscate, avantajele economice furate de vechii nomenclaturiști au generat o neîncredere crescândă în noile state „democratice”. De exemplu, în Cehia, Ungaria și Polonia, disidenții deveniți acum politicieni au fost puși în situația de a recunoaște că idealurile lor de dinainte de prăbușirea regimului fuseseră naive. În acest fel, confruntarea dură cu realitatea postsocialistă i-a făcut pe oameni să privească spre vechiul regim cu nostalgie. În fosta RDG, brusca dominație a valorilor și a puterii Germaniei de Vest asupra unei Germanii neunificate a stârnit sentimente de dezorientare și de pierdere a identității. Asta a produs ceea ce se va numi fenomenul de ostalgie, o dorință a cuiva de a retrăi în RDG prin consumarea produselor de acolo și prin urmărirea posturilor de televiziune care idealizează viața sub comunism. ${ }^{22}$ Același sentiment este experimentat și de majoritatea populației române, drept care Dan Lungu fructifică în romanul său mentalitatea omului simplu, care trebuie să reziste schimbărilor bruște de sistem, dar a cărui memorie nu face decât să idealizeze vremurile apuse.

Romanul Sint o babă comunistă! este structurat pe 29 de capitole, în care cititorul ia contact cu trei Emilii - Mica, de pe vremea când protagonista încă locuia la țară cu părinții ei, Emilia Burac- adolescenta deja mutată la oraș și Emilia Apostoae - membra de partid și soția lui Țucu. Discursul este homodiegetic, se narează la persoana I din perspectiva protagonistei, dar întâmplările nu sunt redate cronologic, ci prin tehnica flashbackului. Din acest punct de vedere, romanul lui Dan Lungu este cu atât mai captivant și stabilește o relație mai apropiată cu cititorul, a cărui memorie este predispusă la aceleași salturi în timp pe care le face naratorulpersonaj, pentru a pune în evidență avantajele comunismului și amintirile dragi din acea perioadă. Amestectul planurilor narative este deosebit de antrenant. Primul dintre ele se axează pe prezent, adică pe criza identitară pe care o experimentează Emilia odată ce constată că amintirile ei despre comunism nu corespund cu părerea generală, astfel încât discursul ei este

22. Maruška Svašek, „Postsocialism and the Politics of Emotions”, în Postsocialism: politics and emotions in Central and Eastern Europe, Berghahn Books, 2008, p. 12. 
debusolat, iar senzația pe care o are este de neapartenență, de inadaptare la noile timpuri. Planul secundar este realizat prin tehnica flashbackului, prezentând industrializarea forțată a populației de la sate și, implicit, împlinirea visului micuței Emilia de a deveni orășeancă, lăsând în spate tezicul (amestecul de balegă și paie) pentru a se răsfăța precum tanti Lucreția, mătușa din partea tatălui, cea mereu parfumată și cu unghiile vopsite.

Planul terț al romanului aduce deliciul publicului cititor, pentru că aici Dan Lungu își pune în aplicare umorul și cunoștințele sociologice, conturând cadrul profesional al atelierului pentru export în care și-a petrecut Emilia toată tinerețea. Nenumărate pagini din roman sunt ocupate de bancurile ceaușiste ale lui nea Mitu și de atmosfera degajată de la locul de muncă al Emiliei, unde doar dimineața se muncea, iar restul zilei era program de voie. Contrastând cu regimul comunist trăit în tranșee, aici muncitorii își ocupau după-amiezele jucând table, spunând bancuri și bând, primind în același timp și cel mai mare salariu, pentru că lucrau pentru export. Cum altfel, amintirile Emiliei sunt dintre cele mai favorabile regimului, întrucât situația ei materială era infinit superioară altor membri ai societății:

Dacă acum aș duce-o jumătate ca pe atunci, aș fi mulţumită. Ce jumătate, pe-un sfert, și tot aș zice săru-mâna. Am avut tot ce miam dorit. E drept, pe atunci nu-ţi doreai prea multe. $\mathrm{Nu}$ știu de ce, dar nu-ţi doreai prea multe. Cred că nu știai că se pot face așa multe cu banii, ca acum. Dar, pentru lumea aia, am avut tot ce-mi poftea inima. Beam numai cafea naturală şi ness... Pe-atunci astea erau o raritate, dar la mine nu era o problemă. Am avut blugi când costau opt sute de lei perechea. Opt sute erau bani, nu glumă! Și nici nu găseai blugi la toate colţurile... Ei bine, eu am avut! Când ieșeam îmbrăcată cu ei, tot cartierul întorcea capul după mine. Kent și BT pentru doctori, nici nu mai spun. Nu exista să nu am în casă câteva pachete, în caz că, Doamne ferește!, dădea vreo boală peste mine sau dacă aveam nevoie de-un concediu medical. Ba chiar fumam și eu ţigări dintr-astea bune, pe vremea când mă prosteam, că doar n-am tras niciodată fumul în piept. ${ }^{23}$

Copilăria Emiliei a fost marcată de lipsuri, ea își amintește de

23. Dan Lungu, op. cit., p.69 
îndeletnicirea sezonieră a părinţilor : pregătirea tezicului, care constă în frământarea balegii, stropirea ei cu apă, amestecarea cu paie, călcatul în picioarele goale, și lăsarea la „dospit“ pentru iarnă. In mod evident, aceasta este cea mai neplăcută amintire din copilăria Micăi, care, pentru a experimenta fie și pentru câteva minute viața roz de orășeancă pe care o duce tanti Lucreția, își va construi în fundul grădinii, în vârful copacului, un „apartament secret”, așa cum văzuse la mătușa ei parfumată și bine îmbrăcată. Trăind în această iluzie până la 17 ani, Emilia va aprecia peste mai mult timp faptul că regimul lui Ceaușescu i-a schimbat căsuța din copac de la țară pe un apartament decent din mijlocul orașului.

Dacă mergem în aceeași linie alegorică precum cea lansată de Petru Cimpoeșu, putem fără doar și poate să considerăm tezicul ca o metaforă a comunismului, a acceptării regimului pentru un trai decent. $\mathrm{Cu}$ alte cuvinte, atât timp cât nu comentezi și-ţi faci datoria, știi că ai cu ce te încălzi la iarnă. Emilia a trăit bine în comunism, chiar dacă știa că privilegiile de care se bucură nu sunt obținute pe cale cinstită. Pâinea, carnea, untul, produse de care restul românilor aproape că uitaseră din cauza lipsei lor de pe rafturi, îi parvin Emiliei prin mijloace favorabile și fără prea mult efort. Astfel, nu degeaba afirmă chiar protagonista că făcea parte din tagma „boierilor”, care se bucurau de program de muncă scurt și ușor, de produse alimentare greu de găsit și chiar și de bani mulți : „(...) parcă eram de pe altă planetă. Undeva, în spate, într-un fel de magazie, aveam o cadă în care curgea permanent apă rece. Acolo stăteau berile și sucurile. (...) Bineînţeles, alcoolul era interzis în fabrică. "24 Acesta e gustul fericirii, motivul pentru care Mica regretă perioada comunismului. Din punctul ei de vedere, avea de toate și îi era bine lângă oamenii cu care lucra. Lipsurile sunt privite ca ceva minor comparativ cu satisfacţiile pe care sistemul le oferă.

Situația Emiliei nu este singulară. Ca ea sunt zeci, poate sute de alți români care se văd aruncați într-o civilizație cu totul nouă, fiind nevoiți să constate doar apusul vremurilor lor și nașterea altora în care nu se vor putea adapta. O epocă în care foștii „comuniști” vor fi priviți ca învinși și repudiați. De aceea, Emilia Apostoae meditează asupra unor teme precum fericirea : „De câţi oameni fericiţi e nevoie în jurul tău ca să fii și tu fericit? “25 Pentru a se accepta pe sine, ca „babă comunistă”, Emilia caută și confirmarea celor din jur, pentru a fi convinsă că e îndreptățită

24. Ibidem, p. 144

25. Ibidem, p. 190 
să regrete comunismul. Brusc, personajul constată nu doar că nu are susținerea persoanelor pe care conta, ci și faptul că este privită ca o ființă naivă, care nici măcar în perioada „de tristă amintire” nu știa cu ce se mănâncă viața. Alice, fata ei, o trezește la realitate, aducându-i în vedere monstruozitățile regimului de care norocoasa Emilia nu aflase niciodată sau pe care le acceptase ca pe ceva ce nu o vizează în mod direct, colega de atelier, Aurelia, actual patroană de alimentară, îi deschide ochii Emiliei cu privire la comportamentul afemeiat al mult iubitului "Șef”, iar Sanda, sora ei mai mică, se declară mult mai mulțumită cu viața ei din prezent, trăind la marginea orașului, unde își poate amenaja o grădină cu legume şi fructe.

$\mathrm{Cu}$ toate acestea, trecutul mai puțin plăcut nu o va părăsi niciodată pe Mica. Mirosul de tezic o va întoarce în timp de fiecare dată când Țucu, soțul ei, se va înapoia de la gospodăria de la țară : „În hol, persista mirosul de grajd (...). Nu mi-a fost greu sa descopăr că pantofii, în striurile de pe talpă, aduseseră câteva amintiri din grajdul Catrinei“ ${ }^{26}$

Finalul cărţii e edificator, propune acceptarea trecerii timpului și ilustrează tranziţia spre democraţie a personajelor, refuzul participării la vot arătând încă o dată inadaptarea lor : De când se uita sora mea la mine ca la o babă comunistă? De ce amintirile nostre erau atât de diferite? De câți oameni fericiţi e nevoie în jurul tău ca să fii fericit? Intr-un târziu, am adormit. Azi dimineaţă m-am trezit bătrână. Mâine? Da, mâine sunt algerile... Cred că o să stau frumuşel acasă și o să... o să găsesc eu ceva de făcut. ${ }^{27}$

Ar fi ușor de crezut că Emilia susține și apără regimul căzut cu toată forța sa, mai ales din exclamația pe care o face la un moment dat : „Sînt o babă comunistă, dacă nu știai. Asta sînt !"28. Dar ea nu este altceva decât un om naiv și debusolat care se trezește aruncat într-o nouă lume, pe care nu o înțelege și cu ale cărei noi valori nu se poate acomoda. Până și păstrarea carnetului de partid este un simplu semn al fricii ca nu cumva comuniștii să se întoarcă la putere și să-i sancționeze pe cei care nu-1 mai au. Emilia asociază comunismul cu propria tinerețe, când îi mergea bine. A-și nega trecutul ar însemna a se nega pe sine și, implicit, a-și pierde identitatea. In cele din urmă, acesta este destinul Emiliei Apostoae, un destin tragic, în ciuda notei umoristice în care este scris romanul.

26. Ibidem, p. 105

27. Ibidem, p. 190

28. Ibidem., p. 51 
Personajul debusolat și deturnat de concepțiile atât de diferite ale celor din jur față de propriile amintiri ajunge pe culmile deznădejdii, refuzând, la final, să-şi mai exercite dreptul la vot. In acest fel conturează Dan Lungu, într-un incredibil demers sociologic, profilul românului nostalgic în literatura noastră.

\section{Ochiul străin. Percepția Celuilalt despre Noi, prin lentila lui Patrick McGuinness}

În admirabila sa lucrare de imagologie literară intitulată Literatura generală și comparată (1994), profesorul francez Daniel-Henri Pageaux discuta importanța pe care o are imaginea în dialogul intercultural. În concepția sa, imaginile create de literatură şi de studiile sociologice asupra unei anumite culturi facilitează apropierea de altele asemenea ei sau, din contră, aflate la polul opus, atât pe harta geografiei, cât și pe harta mentalităților. Pageaux aduce în discuție doi termeni, aparent aflați în contradicție: Eu și Celălalt/Străinul. De fapt, aceștia simbolizează nemuritoarea curiozitate a fiecărei țări sau a fiecărui continent de a lua contact cu vecinătățile lui sau cu spațiile mult mai îndepărtate. Literatura a prilejuit din timpuri vechi acest dialog între culturi, prin intermediul imaginii: „(...) orice imagine provine din conștientizarea, oricât de minimă, a unui Eu raportat la un Altul, a unui Aici raportat la un Acolo. Deci imaginea este expresia, literară sau nu, a unui ecart semnificativ între două realități culturale. Prin ecart regăsim acea dimensiune a străinătății pe care se bazează întreaga concepție comparatistă." ${ }^{29}$ Pornind de la cuvintele lui Pageaux, ar fi limpede ca romanul tunisianului Patrick McGuinness, intitulat Ultimele o sută de zile, să evidențieze o altă lume, o altă civilizație sau cultură, în schimb, volumul său nu face altceva decât să așeze o oglindă în fața României comuniste, în care aceasta să se privească pe sine, în încercarea de a se defini.

În fapt, Ultimele o sută de zile este subintitulat Un roman despre sfârșitul comunismului în România, iar firul narativ se conturează din mărturisirile unui profesor de origine britanică, repartizat la Universitatea din București pentru a preda engleză, care prinde ultimele luni de dictatură ceaușistă din România și este martor al sângeroasei revoluții din decembrie 1989. Perspectiva din care ne privește Străinul, Celălalt este una privilegiată: profesorul se află sub protecția mai marilor statului, are acces la informații care nu le sunt accesibile românilor de rând, cunoaște

29. Daniel-Henri Pageaux, Literatura generală și comparată, ed. Polirom, Iași, 2000, p. 82 
gravitatea situației și simte murmurul revoluției încă de dinainte ca populația să răbufnească, dar, cu toate acestea, nu își dorește să se afle în poziția respectivă. Conștiința îl chinuie, gândindu-se că, spre deosebire de cetățenii țării gazdă, el are beneficiul de a cunoaște dualismul sistemului ceaușist: viața sa relativ liniștită, luxuriantă, avantajoasă (mese fine la Capșa, haine de calitate, post bun, relaţie intimă cu fata unuia dintre superiori) contrastează în mod evident cu mizeria, haosul și veșnica stare de paranoia în care trăiește românul de rând.

Personajul-narator, fără nume, prezintă de-a lungul romanului o Românie duplicitară, în care populația flămânzește, este permanent urmărită de Securitate, trăiește fără apă sau curent electric, iar blocurile de locuințe se contruiesc și se derâmă de la o zi la alta pentru a duce la împlinire planul monumental de „modernizare” al lui Ceaușescu, în timp ce, în același București, piața neagră este în floare, „susține economia orașului”, nomenclaturiștii iau masa în restaurante și cluburi selecte, alături de escorte, iar liderii partidului trăiesc fără să ia seama de ceea ce se pune la cale în subsolurile mahalalelor. Cu alte cuvinte, experiența personajului îl poartă în ambele decoruri, luând contact cu oameni din ambele sfere bucureștene, fără a fi cu adevărat în stare să ia atitudine într-o direcție sau alta. Leo O'Heix, coleg de catedră cu naratorul, care a obținut postul în acelaşi fel ca acesta (fără interviu), este cel care, pe parcursul romanului, limpezește de cele mai multe ori lucrurile, inițiându-l pe prietenul său în lumea „secretă” a Bucureștiului socialist. Leo conduce o afacere pe piața neagră a obiectelor de artă, fiind fascinat de clădirile interbelice distruse de regim și colecționând, cu scopul de a vinde la suprapreț, elemente de decor din epoca apusă. Mai mult decât atât, lucrează la o carte, intitulată Bucureștiul pe cale de dispariție, pentru care se documentează zilnic, pe teren.

Cilea Constantin, fiica demnitarului Manea Constantin și studenta profesorului britanic, devine curând și iubita acestuia, însă relația lor se constituie prin acceptarea reciprocă a misterului care le învăluie existențele. Sergiu Trofim, disident, urmărit îndeaproape de Securitate, este ajutat de personajul-narator să își scrie memoriile, pregătind pentru publicare două variante: una cenzurată, pentru România, și o alta a adevărului, pentru lansare în Franța. Când farsa va fi fost consumată, revoluția va fi deja în toi. Otilia Moranu, asistentă medicală, care a văzut mizeria umană în adevărata ei substanță, îl va însoți în cele din urmă pe narator, depășind împreună perioada sângeroasă din decembrie 1989. Fratele ei, Petre, presupus disident, va muri sfâșiat în capcanele montate în adâncurile 
Dunării. La nivel înalt, soarta României este incertă. Subiectul, punctat pe alocuri de date fictive (nume imaginare, toponime inventate, personaje aluzive, perioade istorice decalate), îi amintește pe soții Ceaușescu de la vizitele oficiale prin oras,, când, ca prin minune, magazinele gem de bunătățuri, iar populația îi adoră, și până la ultimele clipe de viață, precedate de simulacrul de proces de la Târgoviște. În alte episoade, apare Nicu Ceaușescu, întotdeauna în stare de ebrietate, frecventând cluburile în compania animatoarelor. Asistăm, cu alte cuvinte, la deconstrucția treptată și sigură a unei lumi pregătite să renască însă din propria cenușă. Încă din primele pagini se prefigurează „liniștea de dinaintea furtunii". Naratorul vorbește despre "plictiseala" resimțită de România optzecistă: „Plictiseala atinsese o stare extremă în România anilor 80. (...) În Vest, plictiseala era pentru noi ca un moment de relaș, ca o muzică de lift a vieții, care îți alunecă pe lângă ureche. Plictiseala totalitară era altfel. O stare de așteptare deja încărcată de dezamăgire, în care evenimentul şi anticiparea sa se împletesc într-un ciclu neîntrerupt de tensiune şi acalmie." 30 Imediat apoi se amintesc motivele deja devenite literare ale comunismului: cozile la alimente, frigul din case, tăierea curentului electric seară de seară, decretul anti-avort al lui Ceaușescu, pedepsele aplicate trădătorilor de patrie, nașterea grupărilor subterane care puneau la cale emigrări în statele vestice etc. Plictiseala aparentă este însă starea dominantă până spre finele romanului. Despre ea, naratorul notează:

O vedeai ziua întreagă în cozile de la alimentară, când se aduceau conserve nord-coreene de sardele, sticle de şliboviță iugoslavă din cea mai proastă sau pâine cu coaja înnegrită. Oamenii stăteau în temperaturi de sub zero grade sau în căldură insuportabilă și așteptau. Nimeni nu știa ce cantitate se adusese, indiferent ce-ar fi fost. Deseori nici nu știai ce anume se adusese. Puteai să stai la coadă patru ore și să se termine în clipa în care ajungeai la tejghea. Unii uitau pentru ce așteptau atâta sau nu erau în stare să recunoască ce era acel ceva când îl obțineau. Veneai după pâine și te trezeai cu rachiu iugoslav. Uneori obiectivul cozii se schimba când coada ajungea pe la mijloc: o coadă la carne devenea o coadă la teniși chinezești. Nu mai conta indiferent ce-ar fi fost, cumpărai. Acest schimb financiar era doar un stadiu preliminar, căci în câteva ore rețelele de trocuri sau vânzări la

30. Patrick McGuinness, Ultimele o sută de zile, trad. din limba engleză de Ana-Maria Lişman, ed. Polirom, Iași, 2012, p. 9 
negru zbârnâiau de marfă proaspătă. ${ }^{31}$

Descrierea cozii la alimente din paragraful de mai sus poate servi, în bună măsură, cu valoare documentară, poate mai mult decât literară. În strânsă legătură cu pasajul din roman, cercetătoarea Buțea Corina studiază ideea de coadă în memorialistică și observă următoarele:

Acest fenomen al cozii, impus de regimul comunist, are mai multe caracteristici. Regimul comunist contribuia la ceva ce nu-i servea-și anume la o oarecare coeziune socială. În cadrul cozii aveau loc schimburi de opinii,care uneori erau destul de intense și de asemenea confesiunile nu lipseau. În primul rând, interlocutorii nu erau mereu aceiaşi, oamenii care stăteau la coadă nu aveau în jurul lor tot timpul aceleași persoane. Deși poate nu se cunoșteau,interacţiunile între persoanele care aşteptau să le vină rândul erau destul de importante.Se schimbau păreri, impresii, povești de viaţă, se legau relaţii. Chiar dacă exista frica de informatori care impunea evitarea anumitor discuţii sau eliminarea anumitor subiecte, coada este văzută de Adrian Neculau drept „o mică societate”. Chiar dacă putea fi „o mică societate”, lucrul cel mai important care îi aducea pe acei oameni unii lângă alţii era nevoia fizică, naturală de a mânca, existând astfel o concurenţă directă între cei care își pierdeau timpul degeaba și cei care,„apucau” să cumpere. Astfel, coada dădea naștere celor mai perfide caracteristici umane: ura, lăcomia sau violenţa. ${ }^{32}$

Dacă am avea în vedere până și cele mai mici detalii cunoscute de către McGuinness în scrierea romanului său (fata lui, Sarah, a fost martoră a Revoluției decembriste), am putea să afirmăm că, în ciuda caracterului ficțional, romanul său poate fi un document revelator pentru perioada comunismului de la noi. Monumentalitatea (și nu cred că sunt în eroare atunci când folosesc termenul acesta) romanului lui McGuinness constă în fina analiză sociologică a autorului. Este demn de laudă demersul scriitorul și ambiția de a-și concentra puterea creatoare în scopul portretizării României destrămate din 1989. De cele mai multe ori, remarcile făcute de diverse personaje pe parcursul volumului stau mărturie pentru realitatea istorică a țării noastre: „Schimbarea nu este un punct forte al românilor.” ${ }^{33}$ Simpla enunțare a acestei propoziții însumează

31. Patrick McGuinness, op. cit, p. 9

32. Corina Buțea, „Ideea de coadă în memorialistică”, în Studium (Studium revista studenților, masteranzilor şi doctoranzilor in istorie), issue: VII / 2014, p. 60, on www.ceeol.com.

33. Patrick McGuinness, op. cit., p. 319 
toate cele patru volume analizate în studiul de față. De la Firesc, Simion liftnicul, Sînt o babă comunistă! și până la Ultimele o sută de zile, miza generală a autorilor a fost sublinierea unei stări de fapt: deziluzia unei Românii torturate de sub regimul comunist, care crede că schimbarea aduce binele până atunci absent, dar trăiește în schimb inadaptarea la noile vremuri capitaliste.

\section{Concluzii. De ce o literatură despre (post)comunism?}

Ajungând la finalul acestui studiu despre (post)comunismul românesc, inevitabil apare un semn de întrebare cu privire la relevanța unui astfel de subiect pentru literatura contemporană. De unde până unde această tendință de a valorifica „epoca de tristă amintire” în paginile romanelor de azi? În prefața volumului Și eu am trăit în comunism pe care 1-a coordonat în calitate de editor, Ioana Pârvulescu invocă motivele pentru care a inițiat reconstituirea „romanescă” a comunismului. În primul rând, pentru ca existențele și experiențele celor care au trăit pe pielea lor torturile regimului să nu se piardă în universul istoriei: „Uitarea a început imediat ce comunismul a căzut. Deja s-au maturizat, până azi, generatiii care nu mai au ce să uite: s-au născut în altă lume, pe altă planetă. În curând toate aceste detalii vor dispărea cu desăvârșire și nu se va mai ști cum a fost cu adevărat.” ${ }^{4}$ În al doilea rând, pentru a-i „lămuri” pe toți neștiutorii sau pe cei care nu cred în gravitatea regimului: „Să sperăm că această carte e limpede și pentru cei care au cunoscut, și pentru cei care n-au cunoscut vremurile evocate aici și că, la sfârșitul ei, cititorul va putea spune: Sunt lămurit." ${ }^{35} \mathrm{Cu}$ alte cuvinte, volumul Ioanei Pârvulescu s-ar dori a fi un prilej de aducere aminte, pentru cei care au trăit în comunism, și un prilej de luare aminte, pentru cei mai norocoși dintre noi care nu au avut experiența aceasta. Și, nu în ultimul rând, editorul mai nota, în finele prefeței, că: „Nu există vaccin împotriva molimelor istorice. Ar fi foarte simplu ca, încă de la o vârstă fragedă, părinții să-și vaccineze obligatoriu copiii împotriva fascismului, comunismului și a oricărei alte boli mortale care a făcut ravagii de-a lungul timpului. Singurul vaccin împotriva molimelor istorice rămâne cartea." ${ }^{36}$ Pornind de la ultima propoziție, se prefigurează, de fapt, chintesența literaturii cu și despre comunism care încă se scrie în România și nu numai.

34. Ioana Pârvulescu (editor), Și eu am trăit în comunism, ed. Humanitas, București, 2015, p. 9

35. Ioana Pârvulescu, op. cit., p. 12

36. Ibidem. 
$\mathrm{Nu}$, nu există un vaccin contra molimelor istorice, dar o formă de vindecare este, după cum se știe din timpuri străvechi, scrisul. Scrisul are potențial cathartic, este un fel de terapie care nu ajută doar la cicatrizarea rănilor celui care a trăit în comunism, ci este și o formă de putere pe care scriitorul o are abia acum, după căderea regimului. Simpla posibilitate de a scrie fără permanenta frustrare venită din partea cenzurii, de a putea face haz de necaz, de ironiza și de a critica fundamentele regimului, de a exprima, prin gura unor personaje, tot ceea ce ai închistat în tine în anii epocii ceaușiste servește unui scop mai măreț decât este satisfacția personală: este pur și simplu conștientizarea libertății 


\section{BIBLIOGRAFIE}

\section{Bibliografie primară:}

Cimpoeșu, Petru, Firesc, ediția a II-a, Iași, Editura Polirom, 2010.

Cimpoeșu, Petru, Simion liftnicul. Roman cu îngeri și moldoveni, ediția a II-a, Iași, Editura Polirom, 2007.

Cimpoeșu, Petru, Simion liftnicul. Roman cu îngeri și moldoveni, Iași, Editura Polirom, 2011.

Lungu, Dan, Sînt o babă comunistă!', Iași, Editura Polirom, 2011.

McGuiness, Patrick, Ultimele o sută de zile, Traducere de Ana-Maria Lișman, Iași, 2012

\section{Bibliografie secundară:}

Boldea, Iulian, „Reinventarea ficțiunii”, în „Vatra”, nr. 1-2/2018.

Buțea, Corina, „Ideea de coadă în memorialistică”, in Studium (Studium revista studenţilor, masteranzilor și doctoranzilor în istorie), issue: VII I 2014, pages: 57-68, on www.ceeol.com.

Cristea-Enache, Daniel, „La bloc”, în „Ziarul de Duminică”, 6 iunie 2008.

Cristea, Valeriu - „Petru Cimpoeșu”, Revista România Literară, 14 noiembrie, 1985.

Dan, Vasile, „Un prozator empatic” în „Vatra”, nr. 1-2/2018.

Pageaux, Daniel-Henri, Literatura generală și comparată, Iași, Editura Polirom, 2000.

Pârvulescu Ioana (editor), Și eu am trăit în comunism, București, Editura Humanitas, 2015.

Svasek, Maruska, „Postsocialism and the Politics of Emotions”, in Postsocialism: politics and emotions in Central and Eastern Europe, Berghahn Books, 2008.

Turcus,, Claudiu, „Simion liftnicul, după 15 ani”, în „Vatra”, nr. 1-2/2018. T,eposu G., Radu, Istoria tragică și grotescă a întunecatului deceniu literar nouă, București, Editura Humanitas, 1993. 